\title{
Managers' perspective on continuous health education in a region of São Paulo State
}

\author{
Perspectiva dos gestores de uma região do estado de São \\ Paulo sobre educação permanente em saúde \\ Perspectiva de los gestores de una región del estado de São \\ Paulo acerca de la educación permanente em salud
}

Silvana Martins Mishima ${ }^{1}$, Allan Correa Aiub ${ }^{1}$, Anna Francine Gonçalo Rigato ${ }^{1}$, Cinira Magali Fortuna ${ }^{1}$, Silvia Matumoto ${ }^{1}$, Marcia Niituma Ogata², Monica Vilchez da Silva ${ }^{3}$, Ana Carolina Nogueira ${ }^{1}$

${ }^{1}$ Universidade de São Paulo, Escola de Enfermagem de Ribeirão Preto, Ribeirão Preto, SP, Brazil.

${ }^{2}$ Universidade Federal de São Carlos, Centro de Ciências Biológicas e da Saúde, Departamento de Enfermagem, São Carlos, SP, Brazil.

${ }^{3}$ Universidade Federal de São Carlos, Centro de Ciências Biológicas e da Saúde, Departamento de Enfermagem, Programa de Pós Graduação em Enfermagem, São Carlos, SP, Brazil.

\section{ABSTRACT}

Objective: Analysing the concepts of Continuous Health Education - CHE (EPS - in Portuguese), operated by municipal managers and translated into official documents. Method: Qualitative research with the use of official documents and semi-structured interviews with the Municipal Health Secretaries or Coordinators of Primary Health Care in the Northeast Region of São Paulo State, and thematic analysis of empirical material. Results: Results indicate difficulties in the municipalities problematizing their management practices, services and health care; EPS tools presented are insufficient and unsatisfactory for amending the array of problems raised and are still far from the routine of Primary Care services. Conclusion: Despite efforts to implement EPS actions for the strengthening of primary care, the process appears to be incipient.

\section{DESCRIPTORS}

Education, Continuing; Inservice Training; Unified Health System; Primary Health Care; Work.
Correspondence Addressed to:

Allan Correa Aiub

Av. dos Bandeirantes, 3900 - Campus

Universitário - Bairro Monte Alegre

CEP 14040-902 - Ribeirão Preto, SP, Brazil

allan.aiub@usp.br 


\section{INTRODUCTION}

The promotion of research and the creation of technologies of distinct nature occur in the face of needs and concerns caused by new situations or those capable of being improved, which lack effectiveness or face restrictions on some powerful technologies before new dilemmas, paradigms, or joint demands present in society.

Continuous Health Education (EPS), a policy geared to the development of workers and a management tool of the Unified Healthcare System in Brazil (SUS), is leveraged by the principles and guidelines that have guided the former since the health reform movement, and that presents important inflection with the Federal Constitution of 1988 and subsequent legislation. The EPS National Policy proposal is to effectuate intertwined relations between education, health programs and services, and between teaching and health care; from training to sectorial management, institutional development and social control in health ${ }^{(1-2)}$, seeking greater resolving power, satisfaction and adequacy of actions and services offered to the population's health needs.

This proposal is inserted in a scenario of "essentially conservative models, focusing on equipment and organic systems and highly specialized technologies, dependent on procedures and diagnostic and therapeutic support equipment"(3). Traditional models of work organization are inflexible and lack attention to subjective, territorial and contextual aspects, and their inflexibility hampers its optimization $^{(4)}$. EPS enables learning ability and creative coping with its ascendant decentralizing logic, transdisciplinary and active flexible character, cooperating with the development of skills as well as the modification of the means towards institutional democratization ${ }^{(2)}$. As a result, the desired improvement in the quality of health care, "the establishment of critical technical, ethical and humanistic practices" is expected ${ }^{(3)}$, by rereading the scientific purpose, reconciling it with the "art of alterity"(3), making science one of the supports for humanized practices, reconfiguring the training and the purpose of health workers.

By altering the way people handle their work, EPS proposes staff involvement, to act, collaborate and take responsibility for obstacles that may be present. In this context, all are learners and subjects creating new possibilities for shaping of the group power relations. The applied perspective is that different actors can be active in the scenario of training and working, and that events can produce differences; affecting, modifying, and producing jolts in being subject, putting this collective in permanent production, therefore operationalizing significant learning ${ }^{(5)}$.

In other words, it can be said that EPS is sustained by actions grounded by meaningful learning design, and that the analysis of problems/situations that need to be faced in everyday life are developed by the dialogue of different subjects in discussion groups ${ }^{(3-5)}$. However, it is important to consider that this process does not occur in isolation from macro-structural contexts, because EPS will always operate "in the micropolitics of the work process, and in this sense, involves molar (macro) and molecular (micro) levels not as opponents, but as an expression in everyday policies, economies, desires and ways of living life"(5).

It should be noted that despite the scientific literature with respect to EPS practices having increased considerably in the period following the ordinance number 198/GM on February 13, 2004 to the present day, and even after publication of the GM/MS Ordinance 1996/07 revising this policy, there is still a lack of scientific papers that address issues related to $\operatorname{EPS}^{(1,6)}$ with regard to intervention analysis in specific areas, as well as those exploring the perspective taken by the agents involved in the decision-making process. In this sense, the results presented here can collaborate with the reflections on the qualification of attention, the difficulties and the potential of processes from analysis and experiences emerging from EPS practices in local areas, thereby contributing to the strengthening of SUS. Undoubtedly, it is relevant to focus on the initiatives launched in various decision-making levels regarding the EPS actions such as those stimulated by one of the Regional Health Departments (DRS - in Portuguese) of the State of São Paulo - Brazil, which were the focus of the present study. In this sense, to question what EPS concepts support the actions taken by the municipalities participating in the said project.

Thus, the objective was to identify and analyze the EPS concepts operated by local health managers or coordinators of Primary Health Care (PHC) of a region covered by a Regional Health Department in the northeast of São Paulo state - Brazil.

\section{METHOD}

This is descriptive study with a qualitative approach, supported by the concepts of Continuous Health Education (EPS in Portuguese or CHE). The field of research was the coverage area of a Regional Health Department (DRS) located in the northeast of São Paulo - Brazil, comprised of 24 municipalities which are divided into four health regions, forming four management groups, called Regional Intermanagement Committees (CIR), defined according to the criteria established in the Health Pact and later regulations $^{(7-8)}$. These boards received specific names in order to characterize the region ${ }^{(9)}$ and here are represented by colors: Blue, Green, Brown and Purple. All 24 municipalities were involved in the project Continuous Health Education: Strengthening of Primary Healthcare - reorganizing the care and management of Primary Care practices (PFAB - in portuguese) developed since 2008 at the state level, through the Development and Qualification Center for SUS CDQ-SUS of DRS. The project involved 144 employees from different backgrounds belonging to the care network of these 24 municipalities, through the action of DRS, and received support from public universities who worked in the Teaching-Service Integration Committee (CIES in Portuguese) $)^{(10)}$, aimed at strengthening the developed actions in the primary health care network.

Thereby, in theory, all municipalities with their managers and organizers of primary care at some point agreed and participated in at least one EPS action developed in this region that was the focus of PFAB (in Portuguese). 
The commitment of local health managers responsible for the management of health policies at the municipal level is essential for EPS implementation, so the proposal was to analyze the Annual Management Reports (RAG - in Portuguese) for the period of 2008-2009, and also the Continuous Health Education Regional Action Plans (PAREPS - in Portuguese) of 2008 and 2010 of the four health regions, constituting both the sample of secondary data. This time frame corresponds to the start of PFAB and the availability of the documents from the municipalities. Documents were formally requested from the DRS Technical Coordinator, PAREPS from all four health regions for the selected year, and 18 corresponding RAG documents from 18 of the 24 municipalities that comprise the health regions were obtained for analysis. In addition to the health regions, municipalities identified in the examined documents (PAREPS and RAG) are also shown in the results of this study, through color, in order to preserve ethical aspects.

Primary data were produced through semi-structured interviews of Municipal Health Secretaries or Coordinators of primary care, if there was an absence or they were invited by the first. From the group of 24 managers, two were unwilling to participate in the investigation, and one interview was lost due to equipment problems, totaling 21 interviews. For this set of respondents considered as convenience sampling, it is understood as one that considers "people more conveniently available as study participants"(11), meaning those subjects directly linked to the decision-making process at a local level. We used a guide containing the manager identification (position held, training, time in function), related to aspects of the understanding of EPS activities in the development of the Primary Care work, proposals and developed actions. The interviews were conducted from May to October 2011, and digitally recorded with the consent of the subjects and later transcribed for analysis. The 21 managers were labeled with names of flowers, colors and herbs to ensure their confidentiality.

The project was submitted to the Ethics Committee, as required by Resolution 196/96 of the National Health Council, updated by Resolution 466/12, according to protocol number 1085/2009.

It should be noted that the configuration of PAREPS and RAG follow a similar structure for all municipalities, with a very objective explanation of the developed and proposed actions. Thus, the documents of each municipality were read for analysis and the data on EPS was tabulated in columns for each of the years to which they relate and are grouped as presented, indicating the presence (or absence) of EPS practices or supported by its principles, and further if there were targets, implementation, results and evaluations of actions presented. Regarding the interviews, these were analyzed according to content analysis in its thematic modality ${ }^{(12)}$. In this analysis mode, the central concept is the theme, and this in turn is "the unity of meaning that emanates naturally from an analyzed text according to criteria relating to the theory that serves the reading guide"(13). The reading and successive approximation of the interviews allowed for the identification of issues that were confronted and articulated with the issues involved in relation to actions taken and EPS proposals for the review of documents, mediated by the theoretical framework adopted in research.

\section{RESULTS}

In order to characterize each health region, PAREPS addressed the population aspects, establishment of the health service network (focusing on the Primary Care network), epidemiological profile and general characteristics of health care.

The DRS studied attends to almost one million inhabitants, a population profile similar to that of São Paulo ${ }^{(14-15)}$, evidencing the epidemiological transition characterized by increased incidence and prevalence of chronic diseases, instead of infectious diseases ${ }^{(16)}$. In the referred DRS in 2008, the SUS care network had 143 Primary Care (PC) Units, 45 services attending to specialities and 21 hospitals. This constituted an average of one UBS (Primary Care Units) for every 6,593 inhabitants. The region follows specific legislation that were established in the National Primary Care Policies ${ }^{(17)}$, setting the parameter of 30,000 inhabitants per UBS, and those with a Family Healthcare Strategy Unit of every 12 thousand inhabitants (a maximum of three Family Health Teams per UBS).

Considering all the PAREPS and RAG municipalities, it was possible to reach an understanding of the adhesion and the means of conducting the implementation of EPS practices by municipal managers, being the key elements in this process. It should be noted that not all municipalities forwarded or made documents available to DRS, as already pointed out earlier. Of the 18 municipalities that provided documents to RAG in the years 2008 and 2009, about a quarter remained without any changes, maintaining the same goals, objectives, strategies and entries regarding EPS practices.

In the Green Health Region, the analysis of documents presented difficulties encountered by municipalities, problematizing their management and health care practices since the EPS policy tools are incipient and insufficient to change the problems encountered and are still far from the daily requirements of the Primary Care services. Regarding the Brown Health Region, although their documents quote EPS actions, these are superficial and seem to return to the conception of continuing education, since many of the expressions on EPS actions only refer to meetings and training. RAG do not appear to have been used as evaluation tools, as in some municipalities the same reports were presented over different years, were simply copied, or were just limited to the list of procedures performed in the period without indicating actions aimed at planning, implementation or evaluation of results. In the Purple region, there is a lack of information in the RAG relating to EPS actions, a specific indication of how actions in the present RAG show that these are still incipient or non-existent. Regarding the Blue Health Region, it can be observed from the RAG that this region is where most indications of EPS actions are found, as well as a vision that this as a necessary tool for the reorganization of work processes, the qualification of 
workers and the work in PC. Although it is not unanimous among all municipalities of the region, the perspective of EPS as a management tool at a local level is quite clear.

The records of the analyzed documents are predominantly aligned to the speeches of the managers, but they also express contradictions. The managers of the four health regions have different socio-cultural and age profiles, ranging from 30 to 50 years, different graduations that vary from technical school to post-graduation, and in the areas of human, biological, exact and health sciences, indicating extreme diversity as a whole. It is noteworthy to point out that predominantly in the Blue Health Region, most managers had about 1 year of experience in their managerial function. Because it is a political position, managers are appointed in accordance to the elected mayor, which is one of the key aspects for the diverse operating time on the job.

Some managers use EPS as a way of integrating the SUS directive guidelines, pointing to positive participation in PFAB and mentioning some of the targeted results from EPS actions, such as the ability of professionals to directly intervene in the setting of their practice and sharing responsibilities.

\section{(...) after the project there really was an involve- ment of workers who began to see it with new eyes, because there wasn't a worker right here in- volved with health, many people did not know what SUS was (...) and that was when they began to get involved and feel what it was, why they were there, what was their role in the unit (...). Manager Nutmeg}

Another manager pointed out EPS as a means of

(...) thinking of work processes, construction of planning together, in a co-management style, right? And even thinking about work processes (...). Manager Mustard

Managers point out that there are processes of change in the practice of those workers who participated in the PFAB, towards being more concerned about their practice, valuing the continuity of what has been learned, as well as understanding the need of its application in their daily work. Despite not being the prevailing view, it is mentioned in the interviews that the concept of EPS as a possibility to organize the team through meetings, in forming collectives that may be based on multidisciplinary work, given the complexity of the health area, and there is also the clarification that the results are given long-term.
(...) and then we stay, no, let's talk a little about our prenatal care, let's talk a little about our by- pertension, our pre-consultation ... So the start is tough, right? And now we are trying again to do team meetings with a friendlier look towards continuing education. We already have an extra nurse, she (as an educator), is trying to do some- thing, understanding that this is the beginning of a process where in a few years there will be a better result than we what we are able to realize today, right? Manager Lily

Therefore, some managers recognize that PFAB drew attention to the need of focusing on the health team, in order to make them important agents of work change.

The continuity of the action is also cited as inherent of EPS design, as a process of continuous movement, able to qualify the care offered to SUS users, since (...) it opens the mind of the staff (...). Manager Maidenhair

\section{(...) through the participation of these workers in these courses and workshops [PFAB,] I believe we must always continue, right? As the name implies Continuing Education, it has to be really perma- nent and continuous so that we can offer better service to our users (...). Manager Fleur de Lis}

Overall in the speeches, there is also the clarification that the proximity of the managers to the project is relevant, arguing that being close is critical for learning, demonstrating interest and thereby cooperating with the project and the participating professionals.

Also, the exchange of experiences and practices, sharing knowledge in courses and meetings that workers participate in are highlighted by some managers for contributing to the relationship between management and health facilities.

In one of the speeches, the importance of effective exchange between health services and the University is highlighted, emphasizing that partnership can contribute for both. The evaluation of the Service-Academy partnership favors the qualification of services and research, also generating motivation for work.

(...)Yeah, it is a big discussion that I have there,
with her, with the DRS girls, because I think
that because the White municipality is our DRS
center, everything happens there. So, the munici-
palities now are more and more separated to re-
ceive training, to receive joint work of the Uni-
versity. Here we have a very nice job with the
University X, right? Which is the PET team,
they are always here supporting us, and the
projects. It s a great trade, we give them research
material and they give us scientific knowledge in
return, in this exchange we gain a lot. I think the
DRS should do this exchange, they should know,
right? Manager Bromeliad

In many speeches, the EPS centrally appears as offering courses and specific training to employees, with managers stating that the EPS assisted in the training of municipal health professionals, increasing their decision-making and problem-solving power, keeping in mind that better qualified professionals have the possibility of getting better results together with the population:

[the training] interferes in terms of satisfaction right? Because from the moment you see the same people and those professionals who work with us are qualified and trained, we see that the results are positive regarding users, and the answer is positive, it ends well with more determination, right? In general cases, in attending, in welcoming. Manager Paprika 
When prompted to testify about how they have encouraged the implementation of EPS actions in the city, they stress always having encouraged and stimulated the participation of professionals in courses and training, revealing a conceptual mix between EPS and Continuing Education. There is some confusion on the managers' part in reducing efforts related to EPS with more applied courses, indicating a partial understanding of the EPS purposes. This confusion is the most present in all the interviews, and aligns with the findings of the analyzed documents:

\section{(...) stimulating workers in participating in courses (...) I'm encouraging all the employees to come to see me, I accept it and I sign off on it, right? (...) Nursing, or technical, or trajectory control, health inspector, drivers (...). Manager Oregano}

It can be said that there is an alignment between the findings identified in RAG municipalities and the discourse of managers, being relevant that the observation of the lack of effective EPS actions found in RAG reflects the understanding that managers have about it.

The interviews revealed the diversity of EPS conceptions, with a prevailing one that resembles Continuing Education, although we also found the concept that it is a management tool, helping teams develop thinking processes to change the work process organization. EPS was also considered an important strategy, although with no major impact on workers, management or municipality. It is also worth pointing out that some managers had a negative view and a more radical vision for the development of EPS projects, which were seen as distant from reality and as a waste of public resources and workers' time.

\section{DISCUSSION}

PAREPS elaboration should include a planning process of health education actions attending to service needs, contributing to the education of teams in these areas, as a strategic resource for managing work and education in health. In this process, PAREPS should be prepared, discussed and approved by CIR (Regional Intermanagement Committee) and in the end, this document should aim at guiding the process of implementing EPS interventions $^{(10)}$. Because of the regional aspect of PAREPS and considering the situation of all municipalities that comprise a given territory, the decentralization proposed by EPS policy is more likely to succeed, since smaller spheres have more power to be heard in planning local actions. Therefore, PAREPS guide the planning and execution of actions aimed at achieving Pact for Life goals ${ }^{(7)}$, and in addition to the political and organizational aspects, it aims at serving the population through qualified care assistance and intending to implement changes in the epidemiological profile, favoring dialogue with society, along with the institutional limits of SUS.

In keeping with the principles of EPS, PAREPS operationalization is accomplished by the collective of the subject's actions in micropolitical processes that express conceptions of disputes in technical, political and ethical interests $^{(18)}$, in the composition of the health plan, on their surfaces of care production, management, social participation, and others, as in the education plan.

In the analyzed PAREPS and RAG, this dynamic is not yet present, as the same terms presented are repeated year after year in the same terms of the documents, not establishing clear goals that comprise EPS actions, and sometimes not showing actions aligned to epidemiological data and health, thus leaving the perception that these documents meet a lot more formal and bureaucratic requirements than the conformation of a guideline to be followed within the integrated planning for all the municipalities that are part of the specific CIR. What can be observed is an instituted reproduction movement, going in the opposite direction to that envisaged by EPS in its proposition as a policy ${ }^{(1)}$, materialized by way of operating the PAREPS pact as a legal instrument of EPS actions of the municipalities and health regions.

It is important to note that in the way it was presented and considering the presence in PAREPS actions focused almost exclusively on practice, training and courses focusing on specific knowledge and skills, there is still a conception of an educational proposal in a reiterative and technical style ${ }^{(19)}$. This view, although important in order to ensure safe and qualified practices offered to users, does not advance towards more integrated and integral care practices, especially if the proposition of such courses does not emerge from collective processes of problematizing every day work, in order to focus the production of care on the needs of users. This is an important point to be considered, since the education processes in, with and for the work require "to transcend fragmentation, discontinuity, dissonance between theory and practice, and the overlap of technical and operational knowledge in detriment to conjunctural learning"(19).

The term EPS, disseminated by the Pan American Health Organization (PAHO) in the $1970 \mathrm{~s}^{(2,20)}$, reconstructs the concept and the orientation of education in and for the workplace, within its departments, whose purpose is to improve the health of the population from an analysis of the social and economic determinants, to turn them into subjects when placed in the center of the teaching/learning process; based on the pedagogical premise of meaningful learning and problematization of the working process, aiming to transform practices and work organization through self-analysis and self-management, proposals and solutions to the identified problems ${ }^{(2,21-22)}$. This stands as one of the perspectives presented for the technical-political construction of EPS.

The National Policy of Permanent Health Education (PNEPS - in Portuguese) was established as an SUS strategy for management and training of workers, taking the EPS as a management tool that considers the world of work as a means of teaching and learning process. In this sense, there is a perspective of learning production, critical reflection on the work and clinical resolution and promotion of public health by those involved ${ }^{(1,10)}$.

The process of implementation of PFAB in this region marks one DRS management's commitment to implement 
EPS processes continuing the first movement initiated by the Ministry of Health, which bet on a logical and ascendant regional location, and problematization of practices by four actors: the university, social control, workers and management ${ }^{(22)}$.

This perspective is against the EPS procedures established in the country and in the state of São Paulo, from Ordinance GM/MS 1996/07(10), EPS centers are disjointed and give way to Teaching-Service Integration Committees (CIES), which stopped being a decision-making authority with respect to EPS politics to be more of an advisory body. It can be said that despite the Ministry of Health not having revoked the EPS policy, it departed from its original proposal ${ }^{(1)}$ and created legal instruments of EPS institutionalization ${ }^{(7-10)}$, capturing their instituting force. This process might not have had the predominant effect of reproduction found here if EPS was further strengthened as an instrument for change in states and municipalities. But in the social and health aspects, contending forces give rise to new movements, such as the case of EPS in Movement, a developing strategy in the country ${ }^{(18)}$.

The results presented here denote that attempts triggered potentialities in the region with regard to the agreement and learning at work and through work, but still fail to show enough strength to modify EPS perspectives of municipal managers and their advisors, who reveal a fragile understanding and investment in EPS as a management tool in official documents and interviews.

In this way, there is a directionality of the acts of teaching / learning for delivery, which can associate such autonomy and accountability in production opposing the mechanization of actions produced at work, the victimization of workers who do not pose as subjects of producers of work or carriers of the project. In the EPS, the learning strategies are active, where all are learners and subjects of the process. It provides the development of teamwork and it is carried out by the staff in their daily work, where the triggering premise is the analysis of the health work process.

In this manner, understanding the potential of EPS for the transformation of professional and organizational practices of the work process directs the search for other strategies and devices in order to transcend the transmission of knowledge and technical skills ${ }^{(3,19)}$, creating a living space to develop other knowledge; such as knowing how to be a healthcare professional, knowing how to be part of a health team, knowing how to analyze complex and diverse contexts as defined by the health field.

This understanding is still rare in the sum of the speeches by the subjects of this investigation. The speeches of most managers indicate that the engagement of these subjects in the construction of collective spaces for reflection at work and from work are incipient, with the conception of EPS persisting as specific courses, lectures and focused actions in the training of health teams and workers, with greater alignment to the conceptions of Continuing Education.

The joint statements from the managers allowed for identifying that there is still difficulty in understanding EPS as a management tool and device changing in health practices, which may enable the establishment of collective and participatory spaces for the planning of health actions. Some of the managers point to the lack of expanded professional insight involving the team, highlighting the importance of interdisciplinary teamwork, and in this sense, as an important element for the construction of EPS processes that may occur for all the workers. This includes the issue of communication, being fundamental in permanent negotiation processes for the realization of EPS.

On the other hand, even if a sometimes contradictory and superficial view of EPS actions are found, an emerging movement toward building collective spaces and commitment to the qualification of labor and workers with the highest goal can also be identified in a RAG of one of the health regions, and in the collective dialogues of its managers; this being the construction of a health system which works in accordance with comprehensive care. This, even though it only appears mildly, signals a latent possibility of bringing initial presentation and collective insight into action.

The challenge that is being faced points to the idea of the collective in action, and that these collectives are put into action, so it seems necessary that there is a permanent process of self-management and self-evaluation of these collectives in order to reflect on the action at work and seek the most appropriate forms of action to the principles and values placed in its development, in the case of health work and SUS ${ }^{(2,5,19)}$. This is certainly a task of great difficulty, if we consider the form of organization of work in the health care system that has been ongoing, centered on attention to the demands and the hegemony of certain professional categories, reinforcing the existing fragmentation at work and the distance of comprehensive and integrated care.

The participation of workers as a whole and the understanding of EPS as a management tool imply collective commitment to the transformation of relationships and power structures, and these changes must include different dimensions, "ways of thinking, reflecting, a critical eye on the various contexts of being aware of the factors that influence the development of the subjects of critical awareness of reality and society in which they live" ${ }^{\prime(19)}$, creating opportunities for building relationships on which it is power-sharing, and not the exercise of power of one over the other ${ }^{(19)}$.

Another point to be highlighted, and in a way already indicated above, is concerning what we call conceptual confusion on the part of managers to determine practices that reiterate the prospect of training and development in an isolated and fragmented service. This confusion relates to EPS concepts and Continuing Education. The mistakes made explicit by the managers also feature in health personnel training experiences to operate the concepts and practice of EPS, where the EPS actions are still presented as the fulfillment of previously structured courses, and the promotion of events and actions for specific professional categories ${ }^{(5)}$.

Other studies involving different members of health teams point to the reproduction of the same conceptual inaccuracies, a confusion that is also common in other contexts, other realities ${ }^{(23-25)}$. 
It should be noted once again that the EPS is sustained by the assumption of significant learning, or put another way, the training processes and courses should be designed and organized by taking the problematization of the work process with the focus on transforming the professional practices and the organization of work. In this process, the reference should be "the health needs of individuals and populations, of the sectorial management and of social control in health" ${ }^{(26)}$. In this sense, technical-scientific updates are certainly fundamental in health care, and are an important aspect to be considered, but not the only and central idea to be considered, since given the complexity of the production of care and health management, education processes and training must involve dimensions geared toward the production of subjectivity, and the technical skills and knowledge of the SUS ${ }^{(23,25-26)}$.

It is therefore crucial in this process to rethink the spaces that should and can be occupied by different views about the training and education of health personnel movements, and the EPS and Continuing Education may constitute complementary strategies and "that the clear distinction between them allows for the recognition of the space that should be occupying work management" ${ }^{(19)}$.

Even if timidly, managers mainly from the Blue Health Region linked a certain proximity to this set of issues, bringing forth the EPS to imply an extensive network of communication or network of conversations ${ }^{(5)}$ in which the exchange of experiences and possibilities can be built and incorporated in the collective; in conversations with and between the individuals involved, with the focus on learning, the identification of user needs and possible pacts for health care production.

The development of tools make EPS a possible affordable solution to part of the problem raised in this study because, as it is seen, the mistakes/misunderstandings are perpetually passed in descending order from managers to staff, with difficulty at various levels and at various times, committing to the implementation of EPS in its different layers. We live in a time of overlapping paradigms and questioning practices; the method to new approaches of work tends to be delicate and requires adaptations on the part of those who propose them, which can often be as unique as to context of those who exercise them ${ }^{(19,24)}$.

\section{CONCLUSION}

This study presents as a limitation the fact that it contemplates a specific region of a specific state of the country, which certainly is defined by cultural, social and political aspects. On the other hand, the findings can contribute to create breaches for implementation of EPS processes, as well as strengthening weaknesses in current processes.

The set of elements identified in the analysis of empirical data, arising from the dialogues of municipal health secretaries or coordinators in primary care, as well as from the PAREPS and RAG documents analyzed here, indicate that EPS is poorly considered as a strategy to be used in SUS for transforming the training and development of health workers.
The analyzed data of PAREPS, RAG and the interviews with managers show convergences and divergences found in the municipalities with regards to the organizational structure of health services, specifically of primary care, and the organization of care and access to services that are reflected in health indicators, social control and EPS.

The analysis of the documents produced in the health regions and municipalities shows that the EPS actions provided in PAREPS and explained in RAG are still very new/ early, bringing the question as to if they are being effectively developed towards the direction proposed by the National Policy on Continuous Health Education (PNEPS). The observation that the lack of effective actions of EPS found in $\mathrm{RAG}$ is pertinent reflects the limited understanding that managers have about it, and at the same time it signifies public policy operated by these managers. From official documents, it was possible to identify the fulfillment of tasks without a real analysis or evaluation of the planning done for the municipality, since there is no dialogue between the data presented among what is considered as priority and the planned and executed actions.

In the summary of the statements from the managers, we could identify that movement of actions that align with EPS design at a local level was very incipient. It was apparent from all the empirical data that strengthening $\mathrm{PC}$ is directly related to the importance that management gives to this issue, considering the investments in both primary care and in EPS, since these are results that emerge from social production processes in health and education, defined by great complexity and dimensions that go beyond the technical dimension of work.

Despite efforts for the implementation of actions that can assist in the process of strengthening primary health care through PFAB triggered at the state level, most managers that mentioned the EPS did so in a secondary or superficial way, without setting goals or priorities to this aspect. Therefore, data analysis allowed for the identification of concepts that some managers associate to EPS as something important for work in the care network, but with little significant impact and sometimes even being pointed to as non-existent, since it is not understood in its entirety. Also, we noticed the difficulty for managers in understanding the EPS as a management tool. However, one aspect of importance, even though it was presented in a mild way, relates to managers' engagement in the construction of collective spaces for reflection at work and from work, even being still present in the design of the EPS as specific courses, lectures and actions focused on the qualification of teams and health workers.

The question raised was: How could EPS be translated into actions, targets or goals to be achieved if there is still difficulty in understanding around its fundamentals and its purpose? What would be the best way of implementing the emancipatory proposal of EPS if the labor practice, management and demand are so permeated by technical pragmatism? 
RESUMO

Objetivo: Analisar os conceitos de Educação Permanente em Saúde - EPS, operados pelos gestores municipais e traduzidos nos documentos oficiais. Método: Pesquisa qualitativa, com a utilização de documentos oficiais e entrevistas semiestruturadas com os Secretários Municipais de Saúde ou Coordenadores da Atenção Básica de uma Região de Saúde do Nordeste do Estado de São Paulo e análise temática do material empírico. Resultados: Os resultados apontam dificuldades nos municípios em problematizar suas práticas de gestão, dos serviços e da atenção à saúde; as ferramentas da EPS são apresentadas de forma insuficiente e insatisfatória para a alteração do quadro de problemas levantado e ainda distantes do cotidiano dos serviços da Atenção Básica. Conclusão: Apesar dos esforços para implementação de ações de EPS para o fortalecimento da Atenção Básica, o processo mostra-se incipiente.

\section{DESCRITORES}

Educação Continuada; Capacitação em Serviço; Sistema Único de Saúde; Atenção Primária à Saúde; Trabalho.

\section{RESUMEN}

Objetivo: Analizar los conceptos de Educación Permanente en Salud - EPS, llevados a cabo por los gestores municipales y traducidos en los documentos oficiales. Método: Investigación cualitativa, con la utilización de documentos oficiales y entrevistas semiestructuradas a los Secretarios Municipales de Salud o Coordinadores de la Atención Básica de una Región de Salud del Nordeste del Estado de São Paulo y análisis temático del material empírico. Resultados: Los resultados señalan dificultades en los municipios en problematizar sus prácticas de gestión, de los servicios y la atención sanitaria; las herramientas de la EPS se presentan de forma insuficiente e insatisfactoria para la alteración del cuadro de problemas averiguado y todavía lejano del cotidiano de los servicios de la Atención Básica. Conclusión: Pese a los esfuerzos por la implementación de acciones de EPS con vistas al fortalecimiento de la Atención Básica, el proceso se muestra incipiente.

\section{DESCRIPTORES}

Educación Continua; Capacitación en Servicio; Sistema Único de Salud; Atención Primaria de Salud; Trabajo.

\section{REFERENCES}

1. Brasil. Ministério da Saúde. Portaria n. 198/GM, de 13 de fevereiro de 2004. Institui a Política Nacional de Educação Permanente em Saúde como estratégia do Sistema Único de Saúde para a formação e o desenvolvimento de trabalhadores para o setor e dá outras providências [Internet]. Brasília; 2004 [citado 2014 jan. 10]. Disponível em: http://dtr2001.saude.gov.br/sas/PORTARIAS/Port2004/GM/GM-198.htm

2. Brasil. Ministério da Saúde; Secretaria de Gestão do Trabalho e da Educação na Saúde, Departamento de Gestão da Educação em Saúde. Política Nacional de Educação Permanente em Saúde. Brasília; 2006. (Textos Básicos de Saúde, Série Pactos pela Saúde, v.9).

3. Ceccin RB, Feuerwerker LCM. Mudança na graduação das profissões de saúde sob o eixo da integralidade. Cad Saúde Pública. 2004;20(5):1400-10.

4. Deluiz N. Qualificação, competências e certificação: visão do mundo do trabalho. Formação (Brasília). 2001;(2):5-15.

5. Fortuna CM, Franceschini TRC, Mishima SM, Matumoto S, Pereira MJB. Movements of permanent health education triggered by the training of facilitators. Rev Latino Am Enfermagem [Internet]. 2011 [cited 2015 Apr 15];19(2):441-20. Available from: http://www.scielo.br/ pdf/rlae/v19n2/25.pdf

6. Ferraz F, Backes VMS, Mercado-Martinez FJM, Prado ML. Políticas e programas de educação permanente em saúde no Brasil: revisão integrativa de literatura. Saúde Transformação Social. 2012;3(2):113-28.

7. Brasil. Ministério da Saúde. Portaria n. 399/GM, de 22 de fevereiro de 2006. Divulga o Pacto pela Saúde, 2006. Consolidação do SUS e aprova as Diretrizes Operacionais do Referido Pacto [Internet]. Brasília; 2006 [citado 2014 fev. 02]. Disponível em: http://bvsms.saude. gov.br/bvs/publicacoes/prtGM399_20060222.pdf

8. Brasil. Decreto no 7.508, de 28 de junho de 2011. Regulamenta a Lei n. 8080, de 19 de setembro de 1990, para dispor sobre a organização do Sistema Único de Saúde - SUS, o planejamento da saúde, a assistência à saúde e a articulação interfederativa, e dá outras providências [Internet] Brasília; 2011. Disponível em: http://www.planalto.gov.br/ccivil_03/_ato2011-2014/2011/decreto/D7508.htm

9. São Paulo (Estado). Secretaria de Estado da Saúde. Pacto pela Saúde. Plano Diretor de Regionalização - PDR do Estado de São Paulo. São Paulo: SES; 2008.

10. Brasil. Ministério da Saúde. Portaria n. 1996, de 20 de agosto de 2007. Dispõe sobre as diretrizes para a implementação da Política Nacional de Educação Permanente em Saúde e dá outras providências. [Internet] Brasília; 2007 [citado 2014 fev. 02]. Disponível em: http://dtr2001. saude.gov.br/sas/PORTARIAS/Port2007/GM/GM-1996.htm

11. Polit DF, Beck CT, Hungler BP. Fundamentos de pesquisa em enfermagem: métodos, avaliação e utilização. $5^{\text {a }}$ ed. Porto Alegre: Artmed; 2004.

12. Minayo MCS. O desafio do conhecimento: metodologia de pesquisa social (qualitativa) em saúde. 5a ed. São Paulo: Hucitec; 2010.

13. Bardin L. Análise de conteúdo. Lisboa: Edições 70; 2011.

14. São Paulo (Estado). Secretaria de Estado da Saúde, Departamento Regional de Saúde de Araraquara. Plano de Ação Regional de Educação Permanente em Saúde - PAREPS. DRS III - Araraquara: DRS; 2008.

15. São Paulo (Estado). Secretaria de Estado da Saúde, Departamento Regional de Saúde de Araraquara. Plano de Ação Regional de Educação Permanente em Saúde - PAREPS. DRS III - Araraquara: DRS; 2010.

16. Nasri F. O envelhecimento populacional no Brasil. Einstein [Internet]. 2008 [citado 2014 jan. 10];6 Supl. 1: S4-6. Disponível em: http:// prattein.com.br/home/images/stories/Envelhecimento/envelhecimento_popu.pdf 
17. Brasil. Ministério da Saúde. Portaria n. 648/GM, de 28 de março de 2006. Aprova a Política Nacional de Atenção Básica, estabelecendo a revisão de diretrizes e normas para a organização da Atenção Básica para o Programa Saúde da Família (PSF) e o Programa Agentes Comunitários de Saúde (PACS) [Internet]. Brasília; 2007 [citado 2014 mar. 09]. Disponível em: http://bvsms.saude.gov.br/bvs/publicacoes/ prtGM648_20060328.pdf

18. Feuerwerker LCM, Merhy EE. Educação permanente em saúde: educação, saúde, gestão e produção do cuidado [Internet]. [citado 2015 mar. 08]. Disponível em http://eps.otics.org/material/entrada-outras-ofertas/artigos/eps-educacao-saude-gestao-e-producao-do-cuidado/ view

19. Silva LAA, Franco GP, Leite MT, Pinno C, Lima VML, Saraiva N. Concepções educativas que permeiam os planos regionais de educação permanente em saúde. Texto Contexto Enferm. 2011;20(2):340-8.

20. Lopes SRS, Piovesan ÉTA, Melo LO, Pereira MF. Potencialidades da Educação Permanente para a transformação das práticas de saúde. Comun Ciênc Saúde. 2007; 18(2):147-55.

21. Haddad J, Roschke MAC, Davini MC. Educación permanente de personal de salud. Washington: Organización Panamericana da la Salud; 1994. (Serie Desarrollo de Recursos Humanos en Salud, 1000).

22. Ceccim RB. Educação permanente em saúde: desafio ambicioso e necessário. Interface Comum Saúde Educ. 2005;9(16):161-68.

23. Peduzzi M, Guerra DAD, Braga CP, Lucena FS, Silva JAM. Atividades educativas de trabalhadores na atenção primária: concepções de educação permanente e de educação continuada em saúde presentes no cotidiano de Unidades Básicas de Saúde em São Paulo. Interface Comum Saúde Educ. 2009;13(30):121-34.

24. Montanha D, Peduzzi M. Permanent education in nursing: survey to identify the necessities and the expected results based on the workers conception. Rev Esc Enferm USP [Internet]. 2010 [cited 2014 Jan 10];44(3):597-604. Available from: http://www.scielo.br/pdf/reeusp/ v44n3/en_07.pdf

25. Pinto EEP, Araújo MD, Matumoto S, Capozzolo AA, Cardoso MRL, Mishima SM. Desdobramentos da educação permanente em saúde no município de Vitória, Espírito Santo. Trab Educ Saúde. 2010;8(1):77-96.

26. Oliveira FMCSN, Ferreira EC, Rufino NA, Santos MSS. Educação permanente e qualidade da assistência à saúde: aprendizagem significativa no trabalho da enfermagem. Aquichan. 2011;11(1):48-65. 